used in the early diagnosis of invasive candida infections. The same type of procedure is also extremely promising for detecting other pathogens such as viruses. ${ }^{13} 14$ Enzyme immunoassay will probably find a place in the early diagnosis of invasive aspergillosis, which is currently being investigated.

RCW was supported by an MRC retraining award and thanks Professor H Smith and Dr D W R Mackenzie for encouragement.

\section{References}

${ }^{1}$ Bach, M C, et al, Transplantation Proceedings, 1973, 5, 549.

${ }^{2}$ Rubenstein, E, et al, Medicine, 1975, 54, 331.

${ }^{3}$ Baker, B D, Human Infections with Fungi, Actinomycetes and Algae. Berlin, Springer-Verlag, 1971.
4 Dee, T H, and Rytel, M W, fournal of Laboratory and Clinical Medicine, $1975,85,161$.

5 Hommel, M, Truong, T K, and Bidwell, D E, La Nouvelle Presse Médicale, 1976, 5, 2789.

6 Voller, A, Bidwell, D E, and Bartlett, A, Protides of the Biological Fluids, 1976, 24, 751 .

7 Axelsen, N H, and Kirkpatrick, C H, fournal of Immunological Methods, $1973,2,245$.

8 Weiner, M H, and Yount, W J, fournal of Clinical Investigation, 1976, 58, 1045.

9 Voller, A, Bidwell, D E, and Bartlett, A, Bulletin of the World Health Organisation, 1976, 53, 55.

${ }^{10}$ Engvall, E, and Perlmann, P, Immunochemistry, 1971, 8, 871.

11 Evans, E G V, et al, British Medical fournal, 1973, 4, 86.

12 Mackenzie, D W R, and Philpot, C M, Mycopathologia, 1975, 57, 1.

13 Wolters, G, et al, fournal of Clinical Pathology, 1976, 29, 873.

14 Voller, A, et al, fournal of General Virology, 1976, 33, 165.

(Accepted 3 March 1977)

\title{
Continuous-flow plasmapheresis in management of severe rhesus disease
}

\author{
J GRAHAM-POLE, W BARR, M L N WILLOUGHBY
}

British Medical fournal, 1977, 1, 1185-1188

\section{Summary}

Eight patients with severe rhesus disease and expected fetal loss were treated by intensive plasmapheresis using a continuous-flow cell separator. Plasmapheresis was started at 16-27 weeks' gestation, and continued until planned intrauterine transfusion or until the infant was delivered or the rhesus disease became uncontrolled again. Altogether 24 to 2371 of plasma was exchanged over periods ranging from seven to 16 weeks. In seven of the eight patients the anti-D concentration fell during the period of plasmapheresis. Amniotic fluid spectrophotometry values remained below those recorded in the preceding pregnancy in six out of seven women. In five patients an attempt was made to control the rhesus disease by plasmapheresis alone, and two of these women delivered infants who survived. In the other three cases the infants died, one from the idiopathic respiratory distress syndrome and the other two in utero.

These preliminary findings suggest that intensive plasmapheresis with a cell separator may reduce fetal haemolysis and in some cases can sustain this effect until the infant is delivered. Nevertheless, plasmapheresis may best be used to reduce haemolysis until intrauterine transfusions may be given more safely after 30 weeks' gestation.

\section{Introduction}

Continuous-flow cell separators permit plasmapheresis of up to 71 two or three times a week and offer a possible means of

\footnotetext{
Departments of Haematology, Obstetrics, and Child Health, University of Glasgow, Yorkhill, Glasgow G12 8SJ

J GRAHAM-POLE, MRCP, lecturer in child health (now senior lecturer in paediatric oncology, St Bartholomew's Hospital, London EC1A 7BE) W BARR, FRCS, FRCOG, consultant obstetrician

M L N WILLOUGHBY, MD, MRCPATH, consultant haematologist
}

controlling severe rhesus disease. We have used this approach in eight patients with exceptionally severe rhesus isoimmunisation and have tried to answer the following questions: (1) Can circulating maternal anti-D be removed faster than it reaccumulates? (2) Is such removal accompanied by a decrease in fetal haemolysis, as judged by amniotic fluid spectrophotometry? (3) Can intensive plasmapheresis without intrauterine transfusion save affected infants when the mother has had previous rhesus stillbirths?

\section{Patients and methods}

Obstetric and serological details of the patients are shown in tables I and II. The decision to start plasmapheresis was made when the combination of these factors, usually supported by the findings on early amniocentesis spectrophotometry, suggested that the fetus was unlikely to survive with conventional management. Only highly motivated mothers were accepted, and the procedure was fully explained.

Maternal antibody level-To estimate rhesus antibodies we measured both the indirect antiglobulin (Coombs) titre assay and the anti-D immunoglobulin concentration. ${ }^{1}$ The latter is more reliable than antibody titration ${ }^{2}$ and generally correlates with the severity of haemolysis. ${ }^{3}$ All but one of our mothers had levels of IgG higher than $4 \cdot 0 \mathrm{mg} / \mathrm{l}$, mostly much higher, which by itself suggested the presence of severe rhesus disease. ${ }^{4}$

Amniocentesis findings-All except the first patient (case 1) underwent amniotic fluid spectrophotometry performed by the Liley method ${ }^{5}$ before treatment. Though no definite predictions can be made before 25 weeks' gestation, optical density (OD) measured at a wavelength $(\Delta)$ of $450 \mathrm{~nm}$ is probably the best index of severity and is essential to monitor progress. All eight had levels above 0.1 OD unit, five having levels of at least 0.2 OD unit when first measured, which is equivalent to the IUT zone at 34 weeks' gestation.

Plasmapheresis procedure-Plasmapheresis was carried out using an Aminco Cell Separator (American Instrument Company, Maryland). ${ }^{6}$ Volumes ranging from 2.5 to 7.01 of plasma were exchanged for reconstituted freeze-dried plasma or plasma protein fraction. Fresh frozen plasma $(500 \mathrm{ml})$ was given after the latter to replace clotting factors. Heparin to a total dose of about 10000 units was used as anticoagulant, and calcium gluconate $(10 \mathrm{ml} 10 \%)$ was always given at the start and often during the procedure. ${ }^{7}$ Blood samples were taken before and after the procedure. A full blood count, 12 microanalyses (using the SMA/12 Microanalyser ${ }^{8}$ ), and bacteriological culture were performed, 
TABLE I-Obstetric and blood group details of rhesus-affected families

\begin{tabular}{|c|c|c|c|c|c|c|}
\hline \multirow{2}{*}{$\begin{array}{l}\text { Case } \\
\text { No }\end{array}$} & \multirow{2}{*}{$\begin{array}{c}\text { Age } \\
\text { (years) }\end{array}$} & \multirow{2}{*}{$\begin{array}{l}\text { Blood } \\
\text { group }\end{array}$} & \multirow{2}{*}{$\begin{array}{l}\text { Husband's group } \\
\text { and } \mathrm{Rh} \text { genotype }\end{array}$} & \multicolumn{3}{|c|}{ Previous pregnancies } \\
\hline & & & & $\begin{array}{l}\text { No of survivors } \\
\text { unaffected by } \\
\text { rhesus disease }\end{array}$ & $\begin{array}{l}\text { No of survivors } \\
\text { affected by } \\
\text { rhesus disease }\end{array}$ & $\begin{array}{l}\text { No of deaths due to rhesus disease and } \\
\text { gestational ages }\end{array}$ \\
\hline 1 & 31 & $\mathrm{O}$ rr & $\mathrm{O} \mathrm{R}{ }_{2} \mathrm{r}$ & 1 & 1 & 3 , including intrauterine deaths at 26 and \\
\hline 2 & 30 & $\mathrm{AB} \mathbf{r r}$ & O $R_{1} R_{2}$ & 1 & 1 & 3 , including intrauterine deaths at 20 and \\
\hline 3 & 31 & $\mathrm{O} \mathrm{rr}$ & $O R_{1} r$ & $0 \dagger$ & 1 & 0 , but survivor needed 4 intrauterine \\
\hline $4^{*}$ & 30 & A rr & O $R_{1} R_{1}$ & 1 & 0 & 2, including a neonatal death after \\
\hline 5 & 32 & $\mathrm{O} \mathrm{rr}$ & O $R_{1} R_{2}$ & 1 & 2 & $\begin{array}{l}\text { Intrauterine transtusion at } 28 \text { weeks } \\
1 \text { intrauterine death after intrauterine }\end{array}$ \\
\hline \multirow[t]{2}{*}{$\begin{array}{l}6^{*} \\
7 \\
8\end{array}$} & $\begin{array}{l}27 \\
33 \\
38\end{array}$ & $\begin{array}{l}\text { O rr } \\
\text { B rr } \\
\text { A rr }\end{array}$ & $\begin{array}{l}O R_{1} r \\
O \quad R_{1} R_{2} \\
\text { A } R_{1} R_{1}\end{array}$ & $\begin{array}{l}1 \\
1 \\
1\end{array}$ & $\begin{array}{l}0 \\
1 \\
1\end{array}$ & $\begin{array}{l}\text { transfusion at } 32 \text { weeks } \\
2 \text { intrauterine deaths, both at } 28 \text { weeks } \\
2 \text { intrauterine deaths at } 27 \text { and } 33 \text { weeks } \\
4 \text {, including intrauterine deaths at } 29,31 \text {, } \\
\text { and } 32 \text { weeks }\end{array}$ \\
\hline & & & & 7 & 7 & 17 \\
\hline
\end{tabular}

*Fetus survived after plasmapheresis alone.

†Immunised by blood transfusion in childhood.

TABLE II-Plasmapheresis details, antibody levels, and amniotic fluid findings

\begin{tabular}{|c|c|c|c|c|c|c|c|}
\hline \multirow{2}{*}{$\begin{array}{l}\text { Case } \\
\text { No }\end{array}$} & \multirow{2}{*}{$\begin{array}{l}\text { Gestation at start } \\
\text { of plasmapheresis } \\
\text { (weeks) }\end{array}$} & \multirow{2}{*}{$\begin{array}{l}\text { Total cumulative } \\
\text { plasma exchanged } \\
\text { (1) }\end{array}$} & \multirow{2}{*}{$\begin{array}{c}\text { Average amount of } \\
\text { plasma exchanged } \\
(1 / \text { week })\end{array}$} & \multicolumn{2}{|c|}{$\begin{array}{l}\text { Circulating anti-D (mg/l) before and } \\
\text { after plasmapheresis }\end{array}$} & \multicolumn{2}{|c|}{$\begin{array}{l}\text { Amniotic fluid spectrophotometry } \\
\text { (OD units) }\end{array}$} \\
\hline & & & & Before & After & $\begin{array}{c}\text { Maximum in } \\
\text { preceding pregnancy }\end{array}$ & $\begin{array}{c}\text { Maximum in } \\
\text { present pregnancy }\end{array}$ \\
\hline $\begin{array}{l}1 \\
2 \\
3 \\
4^{*} \\
5 \\
6^{*} \\
7 \\
8\end{array}$ & $\begin{array}{l}20 \\
19 \\
20 \\
20 \\
27 \\
20 \\
21 \\
16\end{array}$ & $\begin{array}{r}29 \\
24 \\
73 \\
164 \\
80 \\
237 \\
152 \\
230\end{array}$ & $\begin{array}{r}4 \\
3 \\
10 \\
11 \\
9 \\
15 \\
19 \\
18\end{array}$ & $\begin{array}{r}5 \cdot 5 \\
28 \cdot 3 \\
55 \cdot 7 \\
10 \cdot 0 \\
1.9 \\
12 \cdot 2 \\
15.5 \\
4.8\end{array}$ & $\begin{array}{r}1.5 \\
13.5 \\
4 \cdot 2 \\
7 \cdot 0 \\
2.5 \\
1.5 \\
3.8 \\
2.5\end{array}$ & $\begin{array}{c}0.735 \\
0.285 \\
0.367 \\
0.380 \\
0.294 \\
0.660 \\
\text { (unavailable } \\
0.510\end{array}$ & $\begin{array}{l}0.344 \\
0.384 \\
0.330 \\
0.169 \\
0.221 \\
0.254 \\
0.547) \\
0.270\end{array}$ \\
\hline Mean & 20 & 124 & 11 & $16 \cdot 7$ & $7 \cdot 6$ & 0.462 & $0 \cdot 197$ \\
\hline Significance & & & & \multicolumn{2}{|c|}{$t=2.05 \dagger ; \mathrm{P}<0.05_{\ddagger}^{\dagger}$} & \multicolumn{2}{|c|}{$t=2.89+\S ; \mathrm{P}<0.025$} \\
\hline
\end{tabular}

*Fetus survived after plasmapheresis alone. †Paired $t$ test.

†One-tailed test.
§Only seven pairs were tested.

and rhesus antibody and titre and immunoglobulins (using radial immunodiffusion (Mancini)) were measured.

The amount of plasma exchanged varied with each patient but increased steadily throughout the study period. The range was from 41 a week $(2 \times 21$ exchanges) to over 201 a week ( $4-5 \times 61$ exchanges). In general the maximum possible plasmapheresis was performed from 20 weeks' gestation onwards until or unless serial amniocentesis showed fetal haemolysis to be clearly lessening in severity.

\section{Results}

Figs 1,2, and 3 show the general pattern of anti-D levels during repeated plasmapheresis. The level at the end of each run was about half that of the pretreatment level, but rose again before the next course of plasmapheresis; the longer the interval the greater the rise. Fig 1 shows the striking falls (from 55 to $9 \mathrm{mg} / \mathrm{l}$ ) obtained with an intensive five-day course of plasmapheresis. Fig 2 shows a temporary period of "escape" with rises in antibody between 27 and 29 weeks' gestation, subsiding later during continuing plasmapheresis.

Table II shows changes in anti-D concentrations and amniotic fluid spectrophotometry values that were related to intensity of plasmapheresis. Most patients had high initial antibody levels (mean $16.7 \mathrm{mg} / \mathrm{l}$ ), which were prevented from rising; the value after the final plasmapheresis many weeks later was lower in seven out of eight women (final mean $7.6 \mathrm{mg} / \mathrm{l}$ ). In five it was less than $4.0 \mathrm{mg} / 1$ (about $15 \mathrm{IU} / \mathrm{ml}$ ), below which level fetal death is unlikely in the natural disease. ${ }^{9}$ The fall in individual levels was statistically significant (paired $t$ test: $t=2.05 ; \mathrm{P}<0.05$, one-tailed). Serial amniotic fluid optical density readings ( $\Delta 450 \mathrm{~nm}$ ) almost always remained below those in the preceding pregnancy. The highest reading in the pregnancy studied was significantly lower than that in the previous pregnancy in six of the seven women for whom previous readings are available (paired $t$ test: $t=2.89 ; \mathrm{P}<0.025$, one-tailed).

Figs 2 and 3 show the serial amniotic fluid optical density readings in the two patients (cases 4 and 6) whose babies survived. An initial upward trend was reversed by plasmapheresis, notably in case 6 when the intensity was increased.

Table III shows the obstetric and fetal outcome in the eight cases.

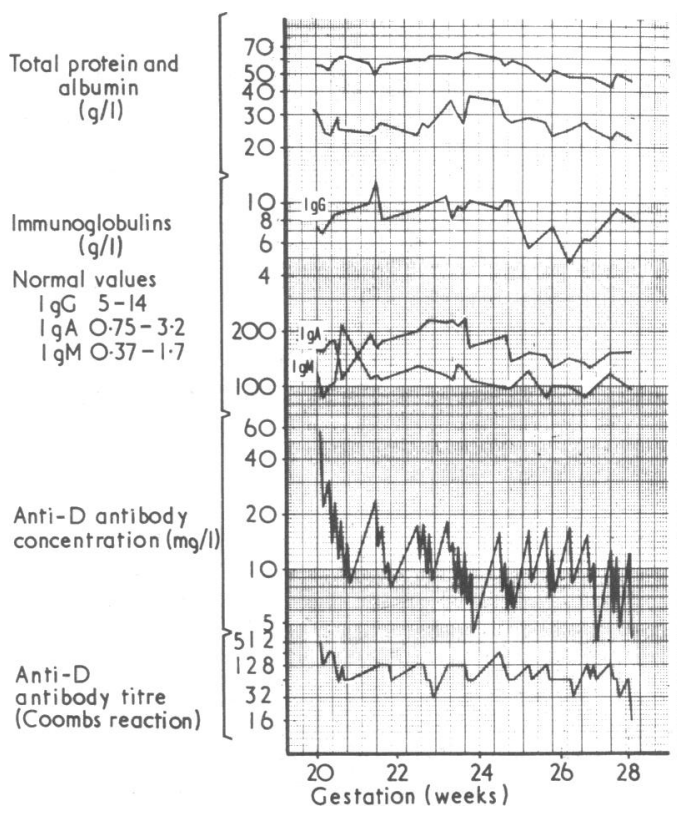

FIG 1-Case 3. Antibody and other plasma protein levels. This diagram first appeared in the Lancet ${ }^{15}$ and is reproduced by permission of the editor of the Lancet. 
In the first three (cases 1-3) our objective was to control the rhesus disease until intrauterine transfusion could safely be performed, since the obstetric history in each case led us to fear intrauterine death before transfusion was feasible. In all three patients this objective was achieved but the fetus died as a direct result of intrauterine transfusion.

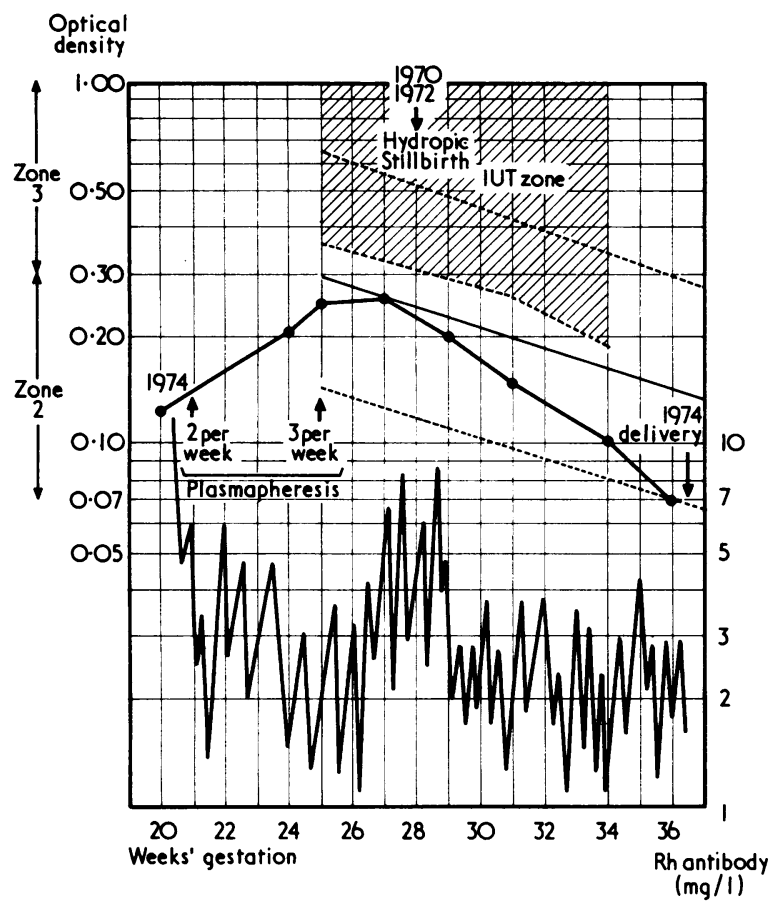

FIG 2-Case 6. Antibody levels and amniotic fluid spectrophotometry values compared with those in previous pregnancy. IUT =intrauterine transfusion.

We therefore changed our policy in the remaining five patients and tried to control the rhesus disease by plasmapheresis alone, using transfusions only when serial amniocentesis suggested failure and impending fetal death. Two infants survived after delivery at 36 weeks' gestation and one died of idiopathic respiratory distress syndrome after delivery at 37 weeks (cord blood haemoglobin $=11 \mathrm{~g} / \mathrm{dl}$, bilirubin $7.5 \mathrm{mg} / 100 \mathrm{ml}(128 \mu \mathrm{mol} / \mathrm{l}))$. In the other two cases (cases 7 and 8) the rhesus disease worsened at 27 and 33 weeks respectively, and neither infant survived; one died at the time of a second intrauterine transfusion (case 7).

The only side effects suffered by the mothers were hypocalcaemic symptoms due to the citrate content of freeze-dried plasma. These were controlled with intravenous calcium gluconate, which was later withdrawn when we started using plasma protein fraction. Immunoglobulin levels remained normal throughout intensive plasmapheresis (fig 1)

\section{Discussion}

Despite current preventive measures, a few patients still have severe rhesus isoimmunisation. This situation will continue because anti-D immunoglobulin prophylaxis will fail in those who have unusually large fetomaternal haemorrhages. There will always be highly motivated women with a history of repeated intrauterine or neonatal deaths due to rhesus disease who will be willing to undergo considerable inconvenience and even slight hazard in the hope of having a normal live infant.

Intrauterine transfusion has been widely used, but the success rate in saving the fetus has been less than $50 \%$ in most series, ${ }^{10} 11$ and it is particularly hazardous before 28 weeks' gestation. As the severity of haemolysis generally correlates with absolute antibody concentrations, ${ }^{9}$ it is logical to try removing antibody by plasmapheresis, particularly as this is harmless to the fetus.

Conventional plasmapheresis using plastic bags and exchanging 1-4 1 a week ${ }^{12-14}$ has given promising results when used either alone between 28 and 34 weeks or together with intrauterine transfusions for more severe disease from an earlier stage of pregnancy (12-14 weeks). In the largest reported series ${ }^{12}$ plasmapheresis alone was successful in 29 out of $40(72.5 \%)$

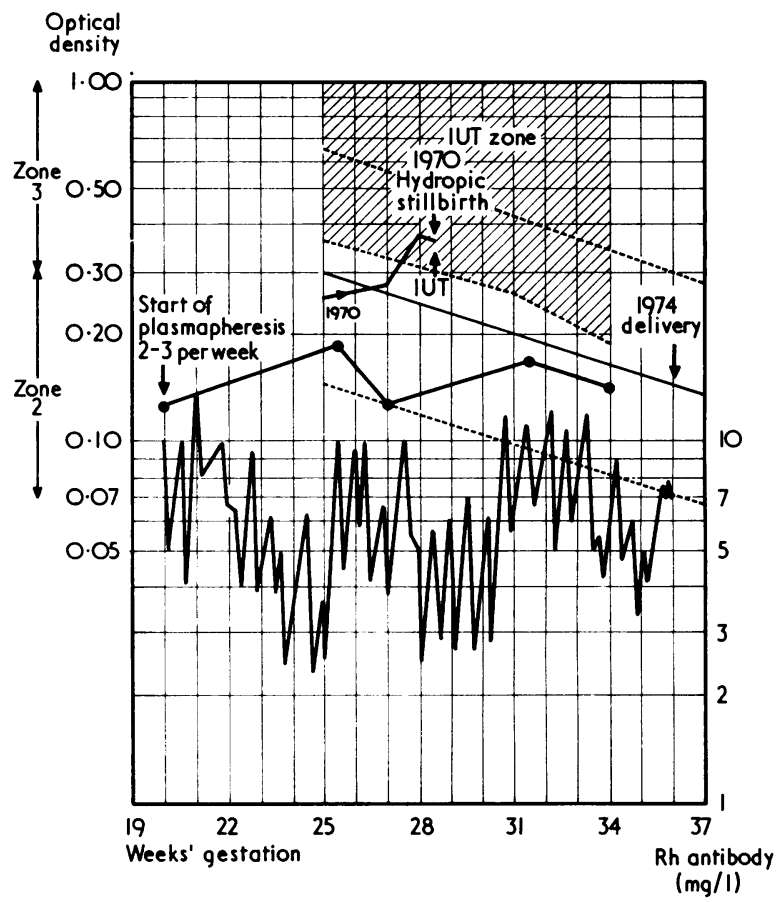

FIG 3-Case 4. Antibody levels and amniotic fluid spectrophotometry values compared with those in previous pregnancy. IUT =intrauterine transfusion

TABLE III-Outcome in patients treated by plasmapheresis

\begin{tabular}{|c|c|c|c|c|c|c|}
\hline \multirow[b]{2}{*}{$\begin{array}{l}\text { Case } \\
\text { No }\end{array}$} & \multirow{2}{*}{$\begin{array}{l}\text { No of weeks } \\
\text { treated }\end{array}$} & \multirow{2}{*}{$\begin{array}{c}\begin{array}{c}\text { Intrauterine } \\
\text { transfusion } \\
\text { (weeks' gestation) }\end{array} \\
\text { ween }\end{array}$} & \multirow{2}{*}{ Fetal outcome } & \multicolumn{3}{|c|}{ Cord blood findings } \\
\hline & & & & $\underset{(\mathrm{g} / \mathrm{dl})}{\text { Haemoglobin }}$ & $\underset{(\mu \mathrm{mol} / \mathrm{l})}{\text { Bilirubin }}$ & $\begin{array}{c}\text { Direct Coombs } \\
\text { test }\end{array}$ \\
\hline \multicolumn{7}{|c|}{ Patients treated by intrauterine transfusion } \\
\hline $\begin{array}{l}1 \\
2 \\
3\end{array}$ & $\begin{array}{l}8 \\
8 \\
9\end{array}$ & $\begin{array}{l}27,29,31 \\
27 \\
28\end{array}$ & $\begin{array}{l}\text { Intrauterine death due to } 3 \text { rd transfusion } \\
\text { Premature delivery at } 28 \text { weeks, after transfusion } \\
\text { Intrauterine death due to transfusion }\end{array}$ & $(=50 \%$ fetal $)$ & 164 & + \\
\hline \multicolumn{7}{|c|}{ Cases in which in intrauterine transfusion was avoided unless plasmapheresis failed to control Rh disease } \\
\hline 4 & $\begin{array}{r}17 \\
9\end{array}$ & $\begin{array}{l}\mathbf{0} \\
\mathbf{0}\end{array}$ & $\begin{array}{l}\text { Live male infant; normal development at } 1 \text { year } \\
\text { Neonatal death at } 37 \text { weeks due to idiopathic respiratory } \\
\text { distress }\end{array}$ & $\begin{array}{l}10 \cdot 0 \\
11 \cdot 0\end{array}$ & $\begin{array}{l}108 \\
128\end{array}$ & $\stackrel{+}{+}$ \\
\hline $\mathbf{6}$ & $\begin{array}{r}16 \\
8\end{array}$ & $\stackrel{0}{27,29}$ & $\begin{array}{l}\text { Live female infant; normal development at } 1 \text { year } \\
\text { Intrauterine death due to } 2 \text { nd transfusion ( } R \text { h disease }\end{array}$ & $15 \cdot 4$ & 99 & + \\
\hline 8 & 13 & 0 & $\begin{array}{l}\text { Neonatal death due to severe Rh disease (Rh disease } \\
\text { not controlled by plasmapheresis) }\end{array}$ & $2 \cdot 0$ & 51 & + \\
\hline
\end{tabular}


patients treated after 28 weeks' gestation and three out of 12 patients treated before 28 weeks' gestation. This highlights the problem of severe disease early in pregnancy, when intrauterine transfusion remains extremely hazardous, yet plasmapheresis alone even using a cell separator to exchange over $20 \mathrm{l}$ a week may fail to control the rate of fetal haemolysis.

Several points have emerged from our study of patients with exceptionally severe rhesus disease treated by intensive plasmapheresis with a cell separator. Firstly, the expected rise in anti-D level as pregnancy progresses can be prevented. Concentrations in seven of our eight patients actually fell $(P<0.05)$, and five had a final level below $4 \mathrm{mg} / \mathrm{l}$ (table II). Secondly, amniotic fluid spectrophotometry readings $(\Delta 450 \mathrm{~nm})$ can be maintained at levels below those recorded in preceding pregnancies. This was achieved in six out of seven patients $(P<0.025)$. The apparent reversal of a rising trend in some patients (figs 2 and 3 ) presumably reflected reduced haemolysis. Thirdly, the fetus can be saved through plasmapheresis alone, even in cases severe enough to warrant treatment from 20 weeks' gestation. Two of the five mothers treated by this policy delivered live babies with cord blood haemoglobin concentrations of 10.0 and $15.4 \mathrm{~g} / \mathrm{dl}$. Both mothers had previously lost two babies as early as 28 weeks' gestation (table I). Lastly, plasmapheresis must be intensive. We were successful only when up to 71 two or three times a week was exchanged. In cases in which we exchanged about 201 weekly plasmapheresis eventually failed to control the rhesus disease (table III).

These preliminary observations suggest that fetal haemolysis may be reduced by intensive plasmapheresis using a cell separator and that in some cases this effect can be sustained by plasmapheresis alone until a viable fetus is delivered at 36-37 weeks. Unfortunately babies still die from prematurity and the idiopathic respiratory distress syndrome, in spite of lessening of haemolysis (table III), and in others haemolysis cannot remain controlled by plasmapheresis alone. These factors must be taken into account when considering a patient for this form of manage- ment. Only highly motivated patients should be selected, as fetal loss after prolonged treatment is particularly distressing.

If the effect of intensive plasmapheresis in reducing fetal haemolysis is accepted its optimum contribution to managing severe rhesus disease may still be to tide the baby over from about 24 weeks until 30 weeks' gestation or later, when intrauterine transfusion is less hazardous.

We thank Dr J Wallace, Dr R Mitchell, and the staff of the Blood Transfusion Service, Law Hospital, for anti-D antibody measurements; Professor I Donald and the obstetricians of the Queen Mother's Hospital for referring patients and for their continuing interest; and Tenovus, Scotland, for financial support. We particularly acknowledge the technical help of Mrs M Davie, Mrs I Kershaw, and Mrs B Pickering, of the department of haematology.

\section{References}

${ }^{1}$ Marsh, W L, Nichols, M, and Jenkins, W J, fournal of Medical and Laboratory Technology, 1968, 25, 335.

${ }^{2}$ Hughes-Jones, N C, Immunology, 1967, 12, 565.

${ }^{3}$ Hughes-Jones, N C, Hughes, M I, and Walker, W, British fournal of Haematology, 1967, 13, 800.

${ }^{4}$ Fraser, I D, Tovey, G H, and Lockyer, W J, fournal of Obstetrics and Gynaecology of the British Commonwealth, 1972, 79, 1074.

${ }^{5}$ Liley, A W, British Medical fournal, 1963, 2, 1107.

${ }^{6}$ Powles, R L, et al, British Medical fournal, 1971, 3, 664.

' Oon, C J, and Hobbs, J R, Clinical and Experimental Immunology, 1975, 20, 1 .

${ }^{8}$ Logan, R W, and Tweedie, T K, Clinica Chimica Acta, 1973, 44, 73.

- Tovey, L A D, and Haggas, W J, British fournal of Haematology, 1971, $20,25$.

${ }^{10}$ Whitfield, J, et al, fournal of Obstetrics and Gynaecology of the British Commonwealth, 1972, 79, 931.

11 Holt, E M, et al, British Medical fournal, 1973, 3, 39.

12 Fraser, I D, et al, Lancet, 1976, 1, 6.

${ }^{13}$ Clarke, C A, et al, Lancet, 1970, 1, 793.

14 Nublat, M, et al, fournal de Gynécologie, Obstétrique et Biologie de la Reproduction, 1972, 5, suppl No $12, \mathrm{p} 227$.

15 Graham-Pole, J, et al, Lancet, 1974, 1, 1051.

(Accepted 23 February 1977)
MRC Unit of Reproductive Biology, Edinburgh EH1 2QW

J E ROBINSON, BSC, research student (present address: Department of Zoology, University College of North Wales, Bangor)

R V SHORT, SCD, FRS, director of unit cycle and at menstruation; the mid-cycle peak was absent when the women were taking oral contraceptives. But the most dramatic changes occurred within 24 hours of parturition, when there was a great increase in breast sensitivity. This may be the key event for activating the suckling-induced discharge of oxytocin and prolactin and inhibiting ovulation during lactation.

\section{Introduction}

The breasts undergo volume changes in response to changing hormone concentrations at puberty, ${ }^{1}$ during the menstrual cycle, ${ }^{2}$ and during pregnancy. ${ }^{3}$ Although the human breast serves a subsidiary function as an organ of sexual attraction, ${ }^{4}$ its primary purpose is to nourish the newborn infant. Breastfeeding also establishes an intimate tactile bond between mother and child, which may be important in establishing and maintaining the mother-infant relationship. ${ }^{56}$

Afferent suckling stimuli from the breast have important endocrine consequences for the mother, as they initiate a 